\title{
Does the sowing period change the grain technological quality of cowpea cultivars?
}

\author{
Fernando da Silva Almeida ${ }^{1}$, Fábio Luiz Checchio Mingotte ${ }^{2}$, Anderson Prates Coelho ${ }^{2} \odot$, \\ Leandro Borges Lemos ${ }^{2}$, Márcio José de Santana ${ }^{1}$, Maurisrael de Moura Rocha ${ }^{3} \mathbb{0}$

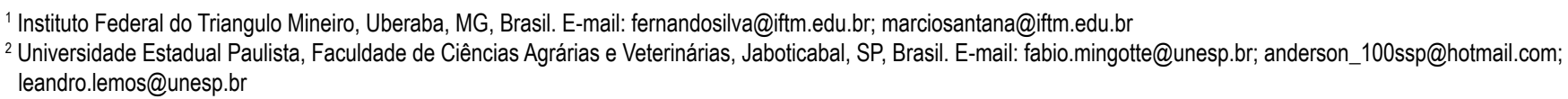

ABSTRACT: The aim of the present study was to evaluate whether the sowing period changes the grain technological quality of cowpea cultivars and to indicate which of these have the highest technological quality when grown in the Center-South region of Brazil. The experiment was conducted in a randomized block design, with a $6 \times 3$ factorial arrangement, using six cowpea cultivars (BRS Itaim, BRS Guariba, BRS Potengi, BRS Cauamé, BRS Novaera and BRS Tumucumaque) and three sowing seasons, with four replicates. The evaluations held referred to the grain size and hydration, cooking time and crude protein content through sulfuric acid digestion. There was an interaction between cowpea cultivars and sowing dates for all analyzed variables. The sowing season alters the grain technological quality of cowpea when under the conditions of the Center-South region of Brazil, with the genotype-season effect dependent. Sowing dates in December and January generated lower technological quality of the cowpea beans. The BRS Tumucumaque cultivar possesses the best grain technological characteristics, having the largest grains with the highest crude protein content, as well as the shortest cooking time.

Key words: genotypes; protein; cooking time; Vigna unguiculata (L.) Walp

\section{A época de semeadura altera a qualidade tecnológica dos grãos de cultivares de feijão-caupi?}

RESUMO: O objetivo do presente trabalho foi avaliar se a época de semeadura altera a qualidade tecnológica dos grãos de cultivares de feijão-caupi e indicar quais cultivares apresentam maior qualidade tecnológica em cultivo na região Centro-Sul do Brasil. $O$ experimento foi realizado em delineamento de blocos casualizados, com arranjo fatorial $6 \times 3$, sendo utilizadas seis cultivares de feijão-caupi (BRS Itaim, BRS Guariba, BRS Potengi, BRS Cauamé, BRS Novaera e BRS Tumucumaque) e três épocas de semeadura, com quatro repetições. As avaliações foram referentes ao tamanho e hidratação dos grãos, tempo de cozimento e teor de proteína bruta através de digestão ácida sulfúrica. Observou-se interação entre cultivares de feijão-caupi e épocas de semeadura para todas as variáveis analisadas. A época de semeadura altera a qualidade tecnológica dos grãos de feijão-caupi nas condições da região Centro-Sul do Brasil, sendo o efeito genótipo dependente. As épocas de semeadura de dezembro e janeiro geram menor qualidade tecnológica dos grãos do feijão-caupi. A cultivar BRS Tumucumaque apresenta as melhores características tecnológicas dos grãos, possuindo os grãos mais graúdos e com maior teor de proteína bruta, além do menor tempo de cozimento.

Palavras-chave: genótipos; proteína; tempo de cozimento; Vigna unguiculata (L.) Walp 


\section{Introduction}

Cowpea, Vigna unguiculata (L.) Walp represents an important source of proteins, calories, vitamins and minerals for the basic diet of the population of several countries, especially in the developing ones (Publio Júnior et al., 2017; Gondwe et al., 2019). Its grains constitute one of the main components of the Brazilian diet, mainly in the North and Northeast regions, where the production is concentrated with more than $70 \%$ of national value (Conab, 2020). In the CenterSouth of Brazil, the production represents $25.8 \%$ of the national value, with an annual cultivated area of 159 thousand ha (Conab, 2020).

Overall, the cowpea has a very competitive production cost in relation to other crops, which contributes to the growing interest of producers from different regions of Brazil (Castro Júnior et al., 2015; Costa et al., 2019). Hence, the crop has been expanding to the Center-South of Brazil, as an off-season alternative, in succession to the crops of soybeans, maize and rice (Costa et al., 2019), attaining a high yield and satisfactory economic return (Almeida et al., 2017; António et al., 2019).

One of the reasons for expanding the cowpea-cultivated area to the Center-South was the development of new cultivars with the erect size and uniform maturation traits, which favor the mechanized harvesting (Freire Filho, 2011; Publio Júnior et al., 2017). Furthermore, it is worth emphasizing that besides the increasing interest of producers in cultivating this species, there has been a greater demand from the Center-South population, mainly for preparing typical dishes, especially in the state of Minas Gerais.

According to Freitas et al. (2013), breeding programs have strived to expand their trial network so that new cowpea cultivars are available to producers in different regions of the country. It is essential that these new cultivars present, in addition to high grain yield, a high technological quality, thus ensuring an equally higher sale price and acceptance by the consumer market (Freire Filho, 2011).

Concerning the crops consumed directly by the population, such as the cowpea, it is worth mentioning that evaluating the grain technological quality of different cultivars is as important as evaluating the productive potential of each genotype. Thus, during the launching process, registering and/or protecting a new cowpea cultivar, some parameters of technological grain quality must be met. For that matter, evaluations of characteristics such as grain size, color, cooking time, the percentage of whole grains after cooking, protein content, grain brightness, and resistance of the cultivar to biotic and abiotic factors (Carbonell et al., 2010) are essential for launching and indicating already existing cultivars. Therefore, studies on the technological quality of the grains from cowpea cultivars are paramount to indicate the best genotypes for the Center-South region of Brazil.

Among the abiotic factors that can reduce the bean grain technological quality, high temperatures and precipitation during the harvesting period can be mentioned (Perina et al., 2014). These factors can cause a greater amount of hardshelled grains, longer cooking time, and stains on the grain tegument as well as diseases, thus reducing the grain quality, its acceptance by the consumer market and the product price (Carbonell et al., 2010). Therefore, sowing at appropriate times is essential so that the crop harvest does not coincide with high temperatures and precipitation, especially in regions where the crop is little cultivated (Perina et al., 2014).

The objective of this study was to evaluate whether the sowing time changes the grain technological quality of cowpea cultivars and to indicate which of these has the highest technological quality under the edaphoclimatic conditions of the Center-South region of Brazil.

\section{Materials and Methods}

The experiment was conducted in Uberaba, Minas Gerais (19 $39^{\prime} 19^{\prime \prime} \mathrm{S}$ and $\left.47^{\circ} 57127^{\prime \prime} \mathrm{W}\right)$, in an altitude of $795 \mathrm{~m}$, average annual rainfall of $1,600 \mathrm{~mm}$ and average temperature of $22.6{ }^{\circ} \mathrm{C}$. The climate, according to Koppen climatic classification, is the Cwa type (subtropical dry winter - temperatures below $18{ }^{\circ} \mathrm{C}$; and hot summer - temperatures above $22^{\circ} \mathrm{C}$ ) (Alvares et al., 2013). The experimental area soil is classified as "Latossolo Vermelho" (Oxisol) with a sandy loam texture (Embrapa, 2013). The soil had the following chemical attributes in its arable layer: $(0.00-0.20 \mathrm{~m}): 6.3 \mathrm{pH}$ $\left(\mathrm{H}_{2} \mathrm{O}\right) ; 24.4 \mathrm{mg} \mathrm{dm}^{-3}$ of $\mathrm{P} ; 89.4 \mathrm{mg} \mathrm{dm}^{-3}$ of $\mathrm{K} ; 1.9 \mathrm{cmolc} \mathrm{dm}^{-3}$ of $\mathrm{Ca} ; 0.7 \mathrm{cmolc} \mathrm{dm} \mathrm{dm}^{-3}$ of $\mathrm{Mg} ; 1.9 \mathrm{cmolc} \mathrm{dm}^{-3}$ of $\mathrm{H}^{+} \mathrm{Al} ; 59.8 \%$ base saturation and $10.0 \mathrm{~g} \mathrm{~kg}^{-1}$ of organic matter.

Figure 1 illustrates the climatic data referring to the maximum and minimum air temperatures and rainfall, collected daily during the conduction of the experiment for the three sowing times.

The mean maximum temperatures for the sowing periods of $14 / 12 / 2012,14 / 01 / 2013$ and 14/02/2013 were 28.7, 28.1 and $27.8{ }^{\circ} \mathrm{C}$, respectively, while the mean minimum temperatures were $19.7,19.4$ and $17.4{ }^{\circ} \mathrm{C}$, also respectively. In turn, the accumulated precipitation for the sowing dates of $14 / 12 / 2012,14 / 01 / 2013$ and 14/02/2013 were 738, 676 and $414 \mathrm{~mm}$.

The experiment was set up in a randomized block design, under a $6 \times 3$ factorial design, consisting of six cowpea cultivars (BRS Itaim, BRS Guariba, BRS Potengi, BRS Cauamé, BRS Novaera and BRS Tumucumaque) and three sowing seasons (14/12/2012, 14/01/2013 and 14/02/2013), with four replicates. Four planting lines composed each plot, each five meters long, with the two central lines considered as the useful area, having $0.5 \mathrm{~m}$ from the ends of each line disregarded. Embrapa Mid-North supplied the seeds of the cultivars used in the present study.

The chosen sowing dates were according to the climatic and cultivation characteristics from most of the CenterSouth region of Brazil. The dates from December to February include the rainy season of the climatic types Cwa and Aw, most common in this region and suitable for obtaining high cowpea yields. Moreover, this same period encompasses 


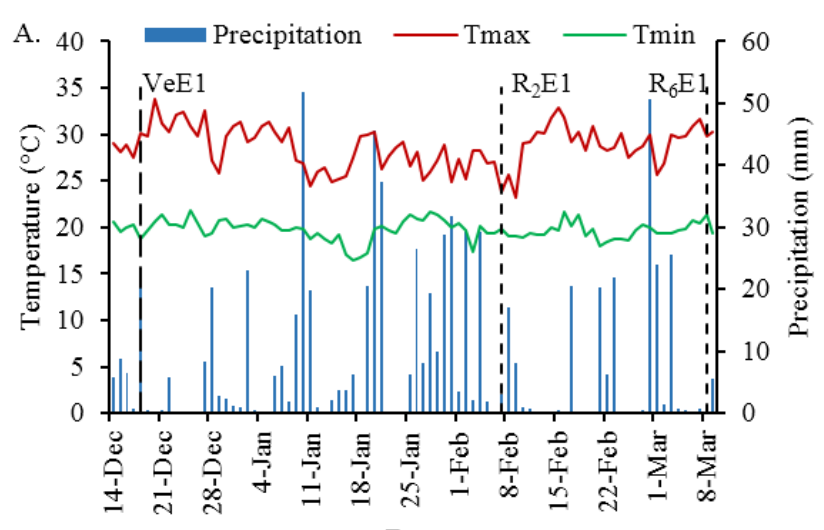

Date
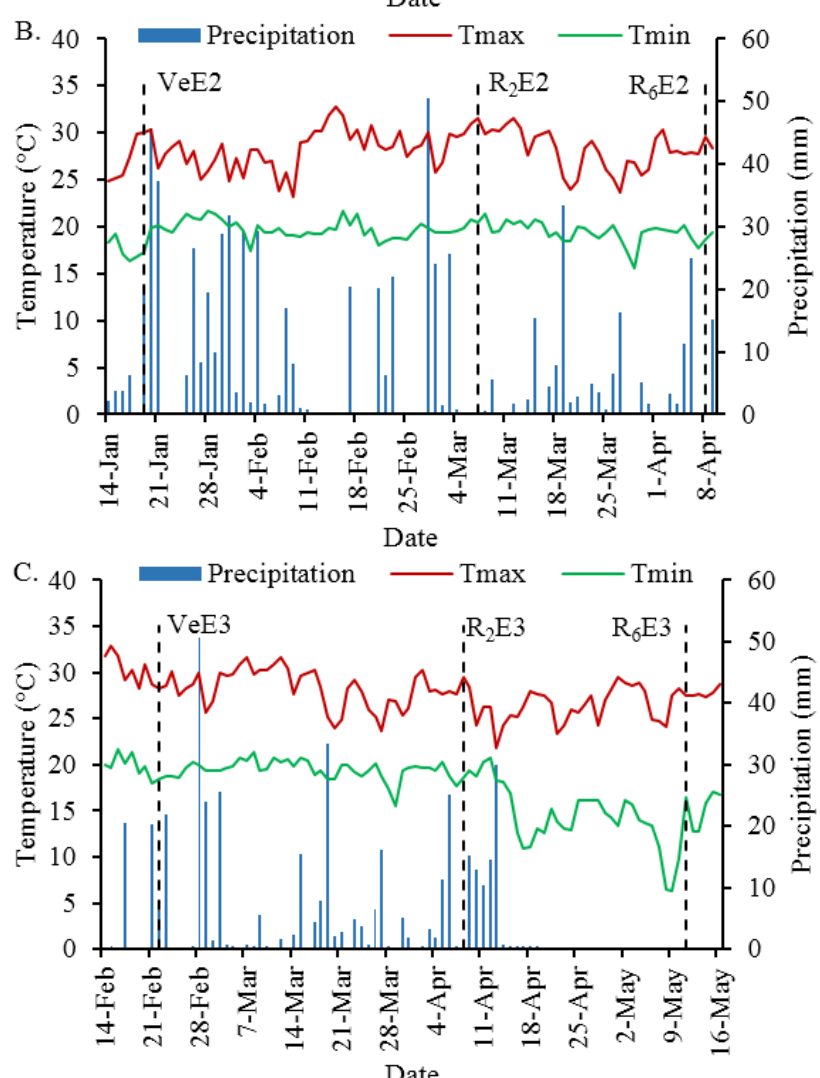

Figure 1. Mean data for every five days of precipitation, maximum and minimum temperature recorded in the experimental area from December 2012 to May 2013 in Uberaba (MG). $V_{e}$ (emergency); $R_{2}$ (full bloom); $R_{6}$ (physiological maturation); E1 (A.) Sowing on 14/12/2012; E2 (B.) Sowing on 14/01/2013; and E3 (C.) Sowing on 14/02/2013.

possible areas for renewal of sugarcane fields and succession of cowpea with other grain crops, such as soybeans and maize, thus generating high applicability of the found results.

The sowing was manual in order to maintain a distribution of eight plants per meter, using a 0.40-m-spacing between rows and having an average population of 200 thousand plants per hectare (Cardoso et al., 2005).

Base fertilization was performed in the sowing furrow with $20 \mathrm{~kg} \mathrm{ha}^{-1} \mathrm{P}_{2} \mathrm{O}_{5}$ and $20 \mathrm{~kg} \mathrm{ha}^{-1} \mathrm{~K}_{2} \mathrm{O}$, in the form of simple superphosphate and potassium chloride, respectively. The topdressing fertilization occurred 25 days after emergence of seedlings, by using $20 \mathrm{~kg} \mathrm{ha}^{-1}$ of nitrogen $(\mathrm{N})$ in urea form
(Cardoso et al., 2005). Weed control was by manual weeding at 15 and 30 days after seedling emergence.

Harvested grains were classified by size, passing through circular sieves of $16 \mathrm{~mm}$ and $15 \mathrm{~mm}$ under agitation, for one minute. The grain mass retained in each sieve was weighed and divided by the total mass, thus calculating the percentage of grains retained in sieves 16 and 15 . The other technological evaluations were performed on grains retained in sieve 15 of each plot.

The grain crude protein content $\left(\mathrm{g} \mathrm{kg}^{-1}\right)$ was calculated by using the equation CPC = total N $\times 6.25$ (AOAC, 1995), in which $\mathrm{N}$ represents the total $\mathrm{N}$ content in the grains, obtained by sulfuric acid digestion (Bataglia et al., 1983).

The cooking time was determined with the aid of an adapted Mattson cooker, consisting of 25 vertical plungers, weighing $90 \mathrm{~g}$ at its extremities, ending in a $1 / 16^{\prime \prime}$ tip. This tip rests on the bean grains during the cooking, and when these are cooked, it perforates the grain, thus moving the plunger. The sample cooking time was obtained when $50 \%+1$ of the plungers, that is, 13 in total, were moved. In order to perform this evaluation, the grains were previously hydrated in distilled water for a period of 12 hours. During the test, water temperature was maintained at $96{ }^{\circ} \mathrm{C}$. More information on the cooking time methodology and the description of Mattson cooker can be found in Ribeiro et al. (2007).

Concerning the hydration capacity of the grains, 50 grams from each sample previously weighed were placed in plastic cups with a volume of $300 \mathrm{~mL}$. After that, these samples received $200 \mathrm{~mL}$ of distilled water. During a period of 18 hours, there were readings of the water volume not absorbed by the grains of each sample every two hours. For this, each sample was poured over a sieve into a graduated cylinder, with accuracy of $2.5 \mathrm{~mL}$, to determine the water volume not absorbed by the grains. Following this procedure, the grains and the same water were placed in a plastic cup for the next reading. At the end of 18 hours, the beans were completely drained and placed on absorbent paper for $10 \mathrm{~min}$ and then weighed.

Regarding the determination of the maximum hydration time, second-degree regressions were plotted for each sample between the water volume absorbed by the grains and the analysis time. The hydration ratio of the grains was obtained by the relation between the final mass of hydrated grains and their initial mass (50 grams). At the end of the test, the percentage of hard-shelled grains was determined, calculated as the ratio between the mass of unhydrated grains in relation to the total hydrated grains mass of each cultivar, after 18 hours.

Data were subjected to analysis of variance (Test F) and, when significant at $5 \%$ probability, means were compared emplying the Tukey test at $5 \%$ probability with the Sisvar software (Ferreira, 2011).

\section{Results and Discussion}

The yield of the sieves with 15 and $16 \mathrm{~mm}$, the percentage of hard-shelled grains, the grain cooking time and the 
Table 1. Mean square and coefficient of variation (CV) regarding the yields of the 16 (RP16) and $15 \mathrm{~mm}$ (RP15) sieves, percentage of hard-shelled grains (HSG), cooking time (CT), grain hydration ratio (HR) of the cowpea cultivars sown under different sowing times.

\begin{tabular}{cccccc}
\hline Treatments & RP16 & RP15 & HSG & CT & HR \\
\hline Cultivars (C) & $4084.9^{* *}$ & $1.231^{* *}$ & $91.8^{* *}$ & $12.6^{* *}$ & $0.12^{* *}$ \\
Sowing times (E) & $2074.9^{* *}$ & $65.8^{* *}$ & $35.1^{* *}$ & $239.6^{* *}$ & $0.14^{* *}$ \\
Interaction C X E & $375.0^{* *}$ & $89.0^{* *}$ & $35.1^{* *}$ & $6.3^{* *}$ & $0.03^{* *}$ \\
CV (\%) & 15.2 & 15.8 & 84.4 & 11.5 & 2.21 \\
General mean & 57.1 & 23.4 & 1.1 & 9.0 & 2.17 \\
\hline
\end{tabular}

** Significant at $1 \%$ of probability by the $\mathrm{F}$ test.

hydration ratio were all influenced by the interaction between cowpea cultivars versus the sowing times (Table 1 ).

The cultivars BRS Itaim and BRS Novaera demonstrated higher percentages of grains retained in sieve 16 during the sowing on $14 / 12 / 2012$ and $14 / 02 / 2013$, with values ranging from 73.3 to $90.5 \%$, respectively (Table 2 ). It is worth emphaiszing that on $14 / 02 / 2012$, the BRS Tumucumaque and BRS Potengi cultivars also had the highest values of grains retained in the sieve 16. During the sowing on $14 / 12 / 2012$, as well as on 14/02/2013 there was a higher percentage of grains retained in sieve 16 for all cultivars. BRS Guariba and BRS Cauamé had the highest percentage of grains in sieve 15 for the three sowing dates (Table 2). We also observed that the BRS Novaera cultivar demonstrated less grain retention in the sieve 15 when sown on 14/12/2012 and 14/02/2013.

The BRS Guariba and BRS Cauamé cultivars were the only ones that did not had the highest sieve 16 yield in any of the sowings. The other cultivars demonstrated a higher sieve yield 16 (mean letter "a") in at least one of the three sowings. Therefore, they are genotypes with smaller grains and which may have less acceptability by the consumer market from the Center-South region.

The grain size criterion has been adopted in the commercialization of grains; however, there is no reference in the literature concerning the methodology for this characteristic in cowpea cultivars. This demonstrates the importance of scientific studies aimed at defining the grain classification methodology that best meets the demands of the various cowpea consumption markets regarding the grain size.

In the present study we observed that, within each sowing, the cultivars with the highest sieve 16 yield, letter a in the mean test, had approximately $70 \%$ of the grains retained in that sieve (Table 2). According to Carbonell et al. (2010), higher common bean cultivars present at least $70 \%$ of the grains retained in the oblong sieve 12 . Hence, there is a similarity between the values of the most consumed bean species in Brazil, although in shape and distinct sizes. Thus, the value of $70 \%$ of grains retained in the $16 \mathrm{~mm}$ circular sieve could be an initial parameter for determining promising cultivars for the consumer market in different regions of Brazil, requiring further studies with more cultivars to validate this reference value.

When analyzing the percentage of hard-shelled grains, only the BRS Cauamé cultivar presented such grains after 18 hours of hydration. However, during the sowing on $14 / 02 / 2013$, this phenomenon was more expressive, having $15 \%$ of hard-shelled grains (Table 2). For Jombo et al. (2017) and Farinelli \& Lemos (2010), the incidence these grains after the hydration period of common bean grains is directly related

Table 2. Unfolding of the interaction of cowpea cultivars and sowing period for the yields of sieve no. 16 and sieve no. 15 .

\begin{tabular}{|c|c|c|c|c|c|c|}
\hline \multirow{4}{*}{ Cultivars } & \multicolumn{3}{|c|}{ Sieve no. 16 yield } & \multicolumn{3}{|c|}{ Sieve no. 15 yield } \\
\hline & \multicolumn{6}{|c|}{ (\% of grains retained) } \\
\hline & \multicolumn{6}{|c|}{ Sowing time } \\
\hline & $14 / \mathrm{Dec}$ & 14/Jan & 14/Feb & 14/Dec & 14/Jan & $14 /$ Feb \\
\hline BRS Itaim & $84.8 \mathrm{abA}$ & $49.6 \mathrm{bB}$ & $73.3 \mathrm{aA}$ & $10.2 \mathrm{~dB}$ & $20.0 \mathrm{bcA}$ & 15.5 bcAB \\
\hline BRS Guariba & $50.7 \mathrm{dA}$ & $37.7 \mathrm{bcA}$ & $41.7 \mathrm{bA}$ & $33.3 \mathrm{abB}$ & $29.9 \mathrm{aB}$ & $40.2 \mathrm{aA}$ \\
\hline BRS Tumucumaque & $71.3 \mathrm{bcA}$ & $72.1 \mathrm{aA}$ & $74.6 \mathrm{aA}$ & $23.4 \mathrm{cA}$ & $16.4 \mathrm{cB}$ & $20.1 \mathrm{bcAB}$ \\
\hline \multirow[t]{4}{*}{ BRS Cauamé } & $27.1 \mathrm{eA}$ & $24.9 \mathrm{cA}$ & $27.9 \mathrm{cA}$ & $37.2 \mathrm{aA}$ & $29.3 \mathrm{aB}$ & $40.5 \mathrm{aA}$ \\
\hline & \multicolumn{6}{|c|}{ Hard-shelled grains (\%) } \\
\hline & \multicolumn{6}{|c|}{ Sowing time } \\
\hline & & 14/Dec & 14/Jan & 14/Feb & & \\
\hline BRS Itaim & & $0.0 \mathrm{bA}$ & $0.0 \mathrm{aA}$ & $0.0 \mathrm{bA}$ & & \\
\hline BRS Cauamé & & $4.1 \mathrm{aB}$ & $1.2 \mathrm{aC}$ & $15.0 \mathrm{aA}$ & & \\
\hline
\end{tabular}

Means followed by the same lowercase letter in the column and uppercase in the row, do not differ by Tukey test at $5 \%$ probability. 
to situations of water stress and high temperatures during the period preceding the grain harvest season, being also a factor affected by the genotype. This is verified for the BRS Caumé cultivar, which was the only one that had hard-shelled grains in all sowing periods.

As for the cooking time of the grains, during the sowing carried on 14/01/2013 and 14/02/2013, the cowpea cultivars did not differ statistically from each other, requiring from 6 to 9 min for cooking (Table 3). During the sowing on 14/12/2012, the BRS Guariba cultivar demonstrated a longer cooking time (17 $\mathrm{min}$ ). This result corroborates with that found by Pereira et al. (2014), who analyzing the cooking time among cowpea cultivars, found a greater value for the BRS Guariba cultivar. When analyzing the sowing period, we noticed that during the sowing on 14/12/2012, the cowpea cultivar grains needed more time for their cooking (from 11 to $17 \mathrm{~min}$ ) (Table 3).

The grain cooking time has become an important factor for acceptance by the consumer of a given cultivar (Oliveira et al., 2013). In Brazil, some cowpea cultivars developed by the breeding program of Embrapa Mid-North have shown cooking times ranging from $13 \mathrm{~min}$ (BRS Tumucumaque) to $23 \mathrm{~min}$ (BRS Potengi), with an average of $18 \mathrm{~min}$ (Freire Filho, 2011). Ávila et al. (2015) observed a mean cooking time of cowpea of approximately $10 \mathrm{~min}$ while Pereira et al. (2014) found values between 2 and $6 \mathrm{~min}$. In the latter, the values are close to those of the present study and confirm the variability in the cooking time of cowpea, either as a function of the cultivar, sowing time and environmental conditions.

In common beans, high rain levels cause changes in the grain physiological quality, thus modifying the integument integrity and water absorption (Farinelli \& Lemos, 2010; Jombo et al., 2017). Such conditions may also have been responsible prolonging the cooking time of different cowpea cultivar grains, since a greater rainfall precipitation occurred in the experiment region during the cycle of the cultivars sown on 12/14/2012 (Figure 1A).

As for the hydration capacity, the grains of the BRS Tumucumaque cultivar demonstrated a higher hydration ratio (2.22 - 2.47) during the three sowing periods, when compared to the others (Table 3 ). In the sowing on $14 / 02 / 2013$, the grains of the cowpea cultivars had a higher hydration ratio (1.95 - 2.47). Kaptso et al. (2008) found a similar result when analyzing two cowpea genotypes, verifying a hydration ratio between 2.25 and 2.45 .
The BRS Cauamé cultivar presented a lower hydration ratio during the sowing on 14/12/2012 and 14/02/2013 (Table 3). Campos et al. (2010) evaluated the hydration ratio after 20 hours of soaking in five cowpea cultivars and their results ranged from 1.96 (BRS Novaera) to 2.42 (BRS Manzagão). Yet, for Rodrigues et al. (2005), the increase or reduction of the hydration capacity is directly related to climatic conditions during the crop cycle, which interfere in both the physiological quality as well as integrity of the bean grains. This was evidenced in the cultivar BRS Cauamé sown on 14/02/2013 (Table 2), in which the highest percentage of hard-shelled grains culminated in a period of greater water restriction (Figure 1C).

The crude protein content of cowpea beans is one of the factors that contribute to their high consumption in certain regions and countries (Gondwe et al., 2019), also an important parameter that can indicate cultivars with greater nutritional value. This nutritional characteristic was not altered by the interaction between cultivars and sowing times, with the effect of factors occurring in an isolated manner (Table 4). The cultivars BRS Guariba, BRS Tumucumaque and BRS Cauamé all demonstrated mean crude protein levels higher than

Table 4. Mean square and coefficient of variation (CV) for the crude protein content from cowpea cultivars sown at different periods.

\begin{tabular}{lc}
\hline \multicolumn{1}{c}{ Treatments } & $\begin{array}{c}\text { Crude protein content } \\
\left(\mathbf{g ~ k g}^{-1}\right)\end{array}$ \\
\hline Cultivar (C) & \\
BRS Itaim & $222 \mathrm{c}$ \\
BRS Guariba & $244 \mathrm{a}$ \\
BRS Tumucumaque & $240 \mathrm{ab}$ \\
BRS Novaera & $227 \mathrm{bc}$ \\
BRS Potengi & $225 \mathrm{bc}$ \\
BRS Cauamé & $233 \mathrm{abc}$ \\
\hline Sowing time (E) & \\
14/Dec & $228 \mathrm{~b}$ \\
14/Jan & $253 \mathrm{a}$ \\
14/Feb & $215 \mathrm{c}$ \\
C & $890.20^{* *}$ \\
E & $8.850 .41^{* *}$ \\
Interaction C $\times \mathrm{E}$ & $251.84^{\mathrm{ns}}$ \\
CV (\%) & 5.32 \\
\hline General Mean & 232 \\
\hline
\end{tabular}

Means followed by the same lower case letter in the column do not differ by Tukey test at $5 \%$ probability. ${ }^{* *}$ significant at $5 \%$ and ns - not significant by the $\mathrm{F}$ test.

Table 3. Unfolding of the interaction between cowpea cultivars and sowing period for cooking time and hydration ratio.

\begin{tabular}{|c|c|c|c|c|c|c|}
\hline \multirow{4}{*}{ Cultivars } & \multicolumn{3}{|c|}{ Cooking time } & \multicolumn{3}{|c|}{ Hydration relation } \\
\hline & \multicolumn{3}{|c|}{ (min) } & \multicolumn{3}{|c|}{ - - ----- } \\
\hline & \multicolumn{6}{|c|}{ Sowing period } \\
\hline & $14 / \mathrm{Dec}$ & $14 /$ Jan & $14 / \mathrm{Feb}$ & 14/Dec & 14/Jan & $14 / \mathrm{Feb}$ \\
\hline BRS Itaim & $11 \mathrm{bcA}$ & $8 \mathrm{aB}$ & $7 \mathrm{aB}$ & $2.12 \mathrm{bB}$ & $2.05 \mathrm{dC}$ & $2.25 \mathrm{cA}$ \\
\hline BRS Guariba & $17 \mathrm{aA}$ & $9 \mathrm{aB}$ & $7 \mathrm{aC}$ & $2.05 \mathrm{cdC}$ & $2.15 \mathrm{bcB}$ & $2.29 \mathrm{bA}$ \\
\hline BRS Tumucumaque & $13 \mathrm{bA}$ & $8 \mathrm{aB}$ & $6 \mathrm{aB}$ & $2.22 \mathrm{aC}$ & $2.35 \mathrm{aB}$ & $2.47 \mathrm{aA}$ \\
\hline BRS Novaera & 11 bcA & $9 \mathrm{aB}$ & $7 \mathrm{aC}$ & $2.10 \mathrm{bcB}$ & $2.10 \mathrm{cdB}$ & $2.25 \mathrm{bcA}$ \\
\hline BRS Potengi & $12 \mathrm{bcA}$ & $8 \mathrm{aB}$ & $7 \mathrm{aB}$ & $2.10 \mathrm{bcc}$ & $2.17 \mathrm{bB}$ & $2.30 \mathrm{bcA}$ \\
\hline BRS Cauamé & $11 \mathrm{cA}$ & $7 \mathrm{aB}$ & $6 \mathrm{aB}$ & $2.00 \mathrm{~dB}$ & $2.17 \mathrm{bA}$ & $1.95 \mathrm{~dB}$ \\
\hline
\end{tabular}

Means followed by the same lowercase letter in the column and uppercase in the row, in each analysis, do not differ by Tukey test at $5 \%$ probability. 
the other analyzed cultivars, thus indicating genotypes with greater nutritional value, especially for the less fortunate part of the population and with limited access to other protein sources.

During the sowing held on 14/01/2013, cowpea cultivars demonstrated higher crude protein levels $\left(253 \mathrm{~g} \mathrm{~kg}^{-1}\right)$, which may have been influenced by numerous factors, from intrinsic characteristics of the cultivar to the influence of climatic factors (Pereira et al., 2014). According to Freire Filho (2011), under the conditions of the Northeast, BRS Cauamé and BRS Tumucumaque cultivars had crude protein levels of 239 and $235 \mathrm{~g} \mathrm{~kg}^{-1}$, respectively, values similar to those in the present study. Hamid et al. (2016) found a mean protein content of $220 \mathrm{~g} \mathrm{~kg}^{-1}$ for cowpea cultivars. Thereby, cowpea has a higher protein content than common beans, where the mean is $200 \mathrm{~g} \mathrm{~kg}^{-1}$ (Farinelli \& Lemos, 2010), making it a nutritional advantage for the cowpea.

Although there was a difference in the time required for maximum grain hydration, no significant interaction between cowpea cultivar factors and sowing dates for this characteristic were found. However, we observed the effect of the factor cultivar in isolation. Regardless of the sowing period, the time required for maximum hydration ranged from 12:24 to $14: 22$ for the BRS Tumucumaque cultivar and from 12:37 to 14:51 for the BRS Cauamé cultivar (Table 5).

The grain hydration process is one of the factors present in the characterization of the grain physiological quality, contributing to the extraction of some constituent of interest in the cooking, in the reduction or elimination of antinutritional factors existing in the grains and, consequently, in the digestibility improvement (Bhokre \& Joshi, 2009). Cavariani et al. (2009) emphasized that the process in question may be affected by the integument permeability, due to variations in its thickness and composition, in addition to being affected by the cultivar and cultivation location. Campos et al. (2010) verified that the BRS Guariba and BRS Novaera cultivars, grown in Boa Vista-RR, presented times for maximum hydration of 11:48 and 11:42 hours, respectively, these values similar to those found in the present study.

Besides changing the technological quality, the sowing period also interferes with the agronomic performance of the cowpea. Evaluating the sowing period effect on this said performance, Almeida et al. (2017) verified that sowing at the beginning of the summer (December) and mid-summer (January) reduces yield in relation to sowing at the end of the same season (February) for most cultivars. According to the authors, this occurs due to the higher incidence of fungal diseases in the rainiest seasons (December and January), affecting the yield of the cultivars. Still, the authors point out that even though it is a season with low rainfall at the end of the cycle, sowing in February under the studied conditions generates greater cowpea yield, since there is an adequate water supply until the flowering at this time, and this fact is associated with the crop tolerance to water deficit. These results were similar to those found in the present study, in which the best grain technological characteristics
Table 5. Time for maximum grain hydration $(\mathrm{TMH})$ of cowpea cultivars sown at different times.

\begin{tabular}{|c|c|c|c|}
\hline Times & Regression equation & $\mathbf{R}^{\mathbf{2}}$ & TMH \\
\hline \multicolumn{4}{|c|}{ BRS Itaim } \\
\hline $14 / 12 / 2012$ & $y=-0.00009 x^{2}+0.126 x+15.42$ & $0.76^{* *}$ & $11: 40$ \\
\hline $14 / 01 / 2013$ & $y=-0.00007 x^{2}+0.108 x+13.69$ & $0.77 * *$ & $12: 51$ \\
\hline $14 / 02 / 2013$ & $y=-0.00009 x^{2}+0.126 x+18.33$ & $0.70 * *$ & $11: 38$ \\
\hline Mean & - & - & 12:03 \\
\hline \multicolumn{4}{|c|}{ BRS Guariba } \\
\hline $14 / 12 / 2012$ & $y=-0.00007 x^{2}+0.104 x+11.96$ & $0.82^{* *}$ & $12: 23$ \\
\hline $14 / 01 / 2013$ & $y=-0.00008 x^{2}+0.119 x+14.97$ & $0.77^{* *}$ & $12: 24$ \\
\hline $14 / 02 / 2013$ & $y=-0.00008 x^{2}+0.128 x+18.16$ & $0.73^{* *}$ & $13: 19$ \\
\hline Mean & - & - & $12: 46$ \\
\hline \multicolumn{4}{|c|}{ BRS Tumucumaque } \\
\hline $14 / 12 / 2012$ & $y=-0.00008 x^{2}+0.130 x+11.69$ & $0.88^{* *}$ & $13: 32$ \\
\hline $14 / 01 / 2013$ & $y=-0.00009 x^{2}+0.134 x+14.03$ & $0.83^{* *}$ & $12: 24$ \\
\hline $14 / 02 / 2013$ & $y=-0.00008 x^{2}+0.138 x+16.62$ & $0.82^{* *}$ & $14: 22$ \\
\hline Mean & - & - & $13: 38$ \\
\hline \multicolumn{4}{|c|}{ BRS Novaera } \\
\hline $14 / 12 / 2012$ & $y=-0.00007 x^{2}+0.111 x+15.40$ & $0.73^{* *}$ & $13: 12$ \\
\hline $14 / 01 / 2013$ & $y=-0.00008 x^{2}+0.116 x+16.15$ & $0.72^{* *}$ & $12: 04$ \\
\hline $14 / 02 / 2013$ & $y=-0.00009 x^{2}+0.130 x+20.49$ & $0.65^{* *}$ & $12: 02$ \\
\hline Mean & - & - & $12: 38$ \\
\hline \multicolumn{4}{|c|}{ BRS Potengi } \\
\hline $14 / 12 / 2012$ & $y=-0.00008 x^{2}+0.116 x+14.24$ & $0.78^{* *}$ & $12: 04$ \\
\hline $14 / 01 / 2013$ & $y=-0.00008 x^{2}+0.124 x+14.13$ & $0.81 * *$ & $12: 52$ \\
\hline $14 / 02 / 2013$ & $y=-0.00009 x^{2}+0.135 x+17.78$ & $0.75^{* *}$ & $12: 30$ \\
\hline Mean & - & - & $12: 46$ \\
\hline \multicolumn{4}{|c|}{ BRS Cauamé } \\
\hline $14 / 12 / 2012$ & $y=-0.00006 x^{2}+0.107 x+6.124$ & $0.95^{* *}$ & $14: 51$ \\
\hline $14 / 01 / 2013$ & $y=-0.00008 x^{2}+0.133 x+7.065$ & $0.95^{* *}$ & $13: 51$ \\
\hline $14 / 02 / 2013$ & $y=-0.00007 x^{2}+0.106 x+6.826$ & $0.92^{* *}$ & $12: 37$ \\
\hline Mean & - & - & $13: 59$ \\
\hline
\end{tabular}

Amount of water absorbed $(\mathrm{mL}) . \mathrm{R}^{2}=$ coefficient of determination; ${ }^{* *}$ significant at $1 \%$ probability by the test $\mathrm{t}$.

of cowpea cultivars were with sowing in February. Thus, high rainfall amounts throughout the cycle, beyond impairing the agronomic performance of cowpea, also reduces the technological quality of its grains.

\section{Conclusions}

The sowing season alters the technological quality of cowpea grains under the conditions of the Brazilian CenterSouth region, with this effect dependent on the genotype.

Sowing in periods with precipitation during the whole crop cycle, such as in December and January, reduces the grain technological quality, but not the protein content. To that end, sowing in the rainiest seasons requires a greater attention when choosing the cultivar, as the difference between their productive potential and quality is greater under this condition than during sowing periods that have less precipitation at the crop cycle end (February).

Since cowpea is a crop with high tolerance to water deficit, cultivation in rainy seasons until the flowering, such as February under the studied conditions, contributes to obtaining high yields and grain quality for the Center-South region of Brazil. 
Among the cultivars, BRS Tumucumaque stands out because, besides having a larger grain size, shorter cooking time and not having hard-shelled grains, it has the highest protein content among the studied genotypes, thus indicating its high nutritional value.

\section{Acknowledgements}

We would like to thank Embrapa Mid-North for supplying the seeds of the cultivars used in this study.

\section{Literature Cited}

Almeida, F.S.; Mingotte, F.L.C.; Lemos, L.B.; Santana, M.J. Agronomic performance of cowpea cultivars depending on sowing seasons in the Cerrado biome. Revista Caatinga, v.30, n.2, p.361-369, 2017. https://doi.org/10.1590/1983-21252017v30n211rc.

Alvares, C.A.; Stape, J.L.; Sentelhas, P.C.; Gonçalves, J.L.M.; Sparovek, G. Koppen's climate classification map for Brazil. Meteorologische Zeitschrift, v.22, n.6, p.711-728, 2013. https:// doi.org/10.1127/0941-2948/2013/0507.

António, G.H.; Bofana, J.; Gimo, F.; Cipriano, S.A. Evaluation of Grain Yield of Two Varieties of Cowpea (Vigna unguiculata) Subjected to Four Agricultural Practices in Gùrué District, Mozambique. Journal of Experimental Agriculture International, v.36, n.5, p.17, 2019. https://doi.org.10.9734/JEAI/2019/v36i530247.

Association of Official Analytical Chemists - AOAC. Official methods of analysis of AOAC International. 16.ed. Washington: AOAC, 1995.

Ávila, B.P.; Santos, M.S.; Nicoletti, A.M.; Alves, G.D.; Elias, M.C.; Monks, J.; Gularte, M.A. Impact of different salts in soaking water on the cooking time, texture and physical parameters of cowpeas. Plant Foods for Human Nutrition, v.70, n.4, p.463-469, 2015. https://doi.org.10.1007/s11130-015-0504-7.

Bataglia, O.C.; Furlani, A.M.C.; Teixeira, J.P.F.; Furlani, P.R.; Gallo, J.R. Métodos de análise química de plantas. Campinas: IAC, 1983. 48 p.

Bhokre, C.K.; Joshi, A.A. Effect of soaking on physical functional and cooking time of cowpea, horsegram and mothbean. Food Science Research Journal, v.6, n.2, p.357-362, 2015. https://doi. org.10.15740/HAS/FSRJ/6.2/357-362.

Campos, J.H.B.C.; Silva, M.T.; Silva, V.P.R. Impacto do aquecimento global no cultivo do feijão-caupi, no Estado da Paraíba. Revista Brasileira de Engenharia Agrícola e Ambiental, v.14, n.4 p.396404, 2010. https://doi.org/10.1590/S1415-43662010000400008.

Carbonell, S.A.M.; Chiorato, A.F.; Gonçalves, J.G.R.; Perina, E.F.; Carvalho, C.R.L. Tamanho de grão comercial em cultivares de feijoeiro. Ciência Rural, v.40, n.10, p.2067-2073, 2010. https:// doi.org/10.1590/S0103-84782010005000159.

Cardoso, M.J.; Melo, F.B.; Lima, M.G. Ecofisiologia e manejo de plantio. In: Freire Filho, F.R.; Lima, J.A.A.; Ribeiro, V.Q. (Eds.). Feijão-caupi: avanços tecnológicos. Brasília: Embrapa Informação Tecnológica, 2005. p.213-225.

Castro Júnior, W.L.; Oliveira, R.A.; Silveira, S.F.R.; Andrade Júnior, A.S. Viabilidade econômica de tecnologias de manejo da irrigação na produção do feijão-caupi, na região dos Cocais-MA. Engenharia Agrícola, v.35, n.3, p.406-418, 2015. https://doi. org/10.1590/1809-4430-Eng.Agric.v35n3p406-418/2015.
Cavariani, C.; Toledo, M.Z.; Rodella, R.A.; França Neto, J.B.; Nakagawa, J. Velocidade de hidratação em função de características do tegumento de sementes de soja de diferentes cultivares e localidades. Revista Brasileira de Sementes, v.31, n.1, p.30-39, 2009. https://doi.org/10.1590/S0101-31222009000100004.

Companhia Nacional de Abastecimento - Conab. Acompanhamento da safra brasileira de grãos. Brasília: Conab, 2020. 66p. (v.7 - safra 2019/20, n.4, quarto levantamento). https://www.conab.gov.br/ info-agro/safras/graos/boletim-da-safra-de-graos/item/downloa d/31573_06a33dea1d278bc862e3efce50226386. 25 Feb. 2020.

Costa, A.C.S.; Souza, L.C.D.; Almeida, A.P.F.; Cavalli, E.; Santos, N.B.; Sofiati, A.D. Adaptação e viabilidade econômica do feijão-caupi como safrinha no Norte de Mato Grosso. Nativa - Revista de Ciências Sociais do Norte de Mato Grosso, v.8, n.2, p.165-175, 2019.

Empresa Brasileira de Pesquisa Agropecuária - Embrapa. Sistema brasileiro de classificação de solo. 3.ed. Brasília: Embrapa, 2013. $353 p$.

Farinelli, R.; Lemos, L. B. Produtividade, eficiência agronômica, características nutricionais e tecnológicas do feijão adubado com nitrogênio em plantio direto e convencional. Bragantia, v.69, n.1, p.165-172, 2010. https://doi.org/10.1590/S000687052010000100021.

Ferreira, D. F. Sisvar: a computer statistical analysis system. Ciência e Agrotecnologia, v.35, n.6, p.1039-1042, 2011. https://doi. org/10.1590/S1413-70542011000600001.

Freire Filho, F.R. (Ed.). Feijão-caupi no Brasil: produção, melhoramento genético, avanços e desafios. Teresina: Embrapa Meio-Norte, 2011. 84p. https://www.embrapa.br/busca-de-publicacoes/-/ publicacao/916831/feijao-caupi-no-brasil-producaomelhoramento-genetico-avancos-e-desafios. 20 Feb. 2020.

Freitas, R.M.O.; Dombroski, J.L.D.; Freitas, F.C.L.; Nogueira, N.W.; Procópio, I.J.S. Produção de feijão-caupi sob efeito de veranico nos sistemas de plantio direto e convencional. Semina: Ciências Agrárias, v.34, n.6, p.3683-3690, 2013. https://doi. org/10.5433/1679-0359.2013v34n6Supl1p3683.

Gondwe, T.M.; Alamu, E.O.; Mdziniso, P.; Maziya-Dixon, B. Cowpea (Vigna unguiculata (L.) Walp) for food security: an evaluation of end-user traits of improved varieties in Swaziland. Scientific Reports, v.9, n.1, p.1-6, 2019. https://doi.org/10.1038/s41598019-52360-w.

Hamid, S.; Muzaffar, S.; Wani, I.A.; Masoodi, F.A.; Bhat, M.M. Physical and cooking characteristics of two cowpea cultivars grown in temperate Indian climate. Journal of the Saudi Society of Agricultural Sciences, v.15, n.2, p.127-134, 2016. https://doi. org/10.1016/j.jssas.2014.08.002.

Jombo, T.Z.; Minnaar, A.; Taylor, J.R.N. Effects of gamma-irradiation on cotyledon cell separation and pectin solubilisation in hard-tocook cowpeas. Journal of the Science of Food and Agriculture, v.98, n.5, p.1725-1733, 2018. https://doi.org/10.1002/jsfa.8645.

Kaptso, K.G.; Njintang, Y.N.; Komnek, A.E.; Hounhouigan, J.; Scher, J.; Mbofung, C.M.F. Physical properties and rehydration kinetics of two varieties of cowpea (Vigna unguiculata) and bambara groundnuts (Voandzeia subterranea) seeds. Journal of Food Engineering, v.86, n.1, p.91-99, 2008. https://doi.org/10.1016/j. jfoodeng.2007.09.014. 
Oliveira, O.M.S.; Silva, J.F.; Ferreira, F.M.; Klehm, C.S.; Borges, C.V. Associações genotípicas entre componentes de produção e caracteres agronômicos em feijão-caupi. Revista Ciência Agronômica, v.44, n.4, p.851-857, 2013. https://doi.org/10.1590/ S1806-66902013000400023.

Pereira, E.J.; Carvalho, L.M.; Dellamora-Ortiz, G.M.; Cardoso, F.S.; Carvalho, J.L.; Viana, D.S.; Freitas, S.C.; Rocha, M.M. Effects of cooking methods on the iron and zinc contents in cowpea (Vigna unguiculata) to combat nutritional deficiencies in Brazil. Food \& Nutrition Research, v.58, n.1, p.20694, 2014. https://doi. org/10.3402/fnr.v58.20694.

Perina, E.F.; Carvalho, C.R.L.; Chiorato, A.F.; Lopes, R.L.T.; Gonçalves, J.G.R.; Carbonell, S.A.M. Technological quality of common bean grains obtained in different growing seasons. Bragantia, v.73, n.1, p.14-22, 2014. https://doi.org/10.1590/brag.2014.008.
Públio Júnior, E.; Morais, O.M.; Rocha, M.M.; Públio, A.P.P.B.; Bandeira, A.S. Características agronômicas de genótipos de feijão-caupi cultivados no sudoeste da Bahia. Científica, v.45, n.3, p.223-230, 2017. https://doi.org/10.15361/19845529.2017v45n3p223-230.

Ribeiro, N.D.; Cargnelutti Filho, A.; Poersch, N.L.; Rosa, S.S.D. Padronização de metodologia para avaliação do tempo de cozimento dos grãos de feijão. Bragantia, v.66, n.2, p.335-346, 2007. https://doi.org/10.1590/S0006-87052007000200018.

Rodrigues, J.A.; Ribeiro, N.D.; Cargnelutti Filho, A.; Trentin, M.; Medianeira, P.; Londero, G. Qualidade para o cozimento de grãos de feijão obtidos em diferentes épocas de semeadura. Bragantia, v.64, n.3, p.369-376, 2005. https://doi.org/10.1590/S000687052005000300006 . 